\title{
PELATIHAN PEMBUATAN VIDEO PEMBELAJARAN DENGAN MENGGUNAKAN POWERPOINT DI MI MUHAMMADIYAH WANGON
}

\author{
Ali Nur (khsan'), Muslimin Hidayat ${ }^{2)}$, Jali Suhaman') \\ 1)Program Studi Informatika, Fakultas IImu Komputer, Universitas Amikom Purwokerto, Purwokerto, Jawa Tengah, \\ Indonesia \\ 2)Program Studi Teknologi Informasi, Fakultas IImu Komputer, Universitas Amikom Purwokerto, Purwokerto, Jawa \\ Tengah, Indonesia
}

Corresponding author : Ali Nur Ikhsan

E-mail : alinurikhsan@amikompurwokerto.ac.id

Diterima 15 April 2021, Direvisi 28 April 2021, Disetujui 01 Mei 2021

\begin{abstract}
ABSTRAK
MI Muhammadiyah Wangon merupakan salah satu sekolah yang mempunyai tenaga pendidik atau guru dengan rentang usia yang variatif, dalam menyajikan bahan ajar para guru mempunyai cara yang variatif juga. Di masa pandemi Covid-19 ini para guru dalam menyajikan bahan ajar masih merasa kesulitan untuk membuat video pembelajaran yang komunikatif dan interaktif. Tim pengabdian kepada Masyarakat (PkM) memberikan pelatihan pembuatan video pembelajaran dengan menggunakan PowerPoint. Metode yang digunakan dalam pelatihan ini yaitu berupa workshop. Tim PkM melakukan pelatihan secara langsung dengan 1 narasumber sebagai pemateri workshop dan 2 pendamping untuk mendampingi peserta dalam pelaksanaan workshop. Pelatihan ini dapat menambah pengetahuan dan kemampuan peserta dalam membuat video pembelajaran yang komunikatif dan interaktif.
\end{abstract}

Kata kunci: pelatihan; video; interaktif; powerpoint; workshop.

\section{ABSTRACT}

MI Muhammadiyah Wangon is one of the schools that has mentors or teachers with various age ranges, and has various way of presenting teaching materials as well. During the Covid-19 pandemic, teachers in presenting teaching materials still found it difficult to make communicative and interactive learning videos. The community service team (PkM) provides training on making learning videos using PowerPoint. The method used in this training is a workshop. The PkM team conducts direct training with 1 person as a speaker and 2 assistants to assist participants in the implementation of the workshop. This training can increase the knowledge and abilities of participants in making communicative and interactive learning videos.

Keywords: training; video; interactive; power point; workshop.

\section{PENDAHULUAN}

Madrasah Ibtidaiyah Muhammadiyah Wangon terletak di jalan kauman No. 12 RT. 01 RW. 01 Desa Wangon, Kecamatan Wangon, Kabupaten Banyumas, Provinsi Jawa Tengah dengan luas tanah wakaf $1480 \mathrm{~m}^{2}$. MI Muhammadiyah Wangon berstatus sekolah swasta dengan nilai akreditasi A Sesuai dari data yang diperoleh Data Pokok Pendidikan Islam Kementerian Agama Republik Indonesia. Sekolah tersebut memiliki siswa yang terdiri dari laki-laki 186 siswa dan 126 siswi.

MI Muhammadiyah Wangon telah menerapkan kurikulum 2013 sesuai dengan aturan yang berlaku sampai saat ini. Fasilitas yang tersedia dalam menunjang kegiatan belajar mengajar antara lain laboratorium dan perpustakaan serta fasilitas lainnya yang secara umum digunakan dalam menunjang kegiatan lainnya seperti lapangan olahraga, akses internet, dan sumber arus listrik yang memadai.

Guru-guru yang mengajar di MI Muhammadiyah Wangon berjumlah 25 orang yang masuk ke dalam rentang usia yang variatif. Berdasarkan data yang dihimpun dari Data Pokok Pendidikan Islam Kementerian Agama Republik Indonesia, pada bagian umur guru dikelompokkan ke dalam beberapa golongan. Golongan pertama dengan rentang usia 21-30 tahun. Golongan kedua dengan rentang usia 31-40 tahun. Golongan ketiga dengan rentang usia 41-50 tahun(EMIS, 2020).

Komposisi guru yang variatif di Ml Muhamadiyah, para guru diharuskan untuk mempunyai gagasan yang inovatif. Hal ini tentunya sangat berpengaruh di masa pandemi Covid 19. Terselenggaranya pendidikan di masa pandemi menjadi sebuah tantangan tersendiri di dunia pendidikan khususnya di 
Indonesia. Tantangan tersebut tentunya berhubungan dengan banyak faktor baik dari guru ataupun siswa.

Dalam menyajikan bahan ajar para guru dituntut untuk dapat professional dalam memberikan materi yang komunikatif dan interaktif bagi para siswa. Untuk itu perlu adanya media pembelajaran yang menjadi alat untuk membantu proses belajar mengajar sehingga makna pesan yang disampaikan menjadi lebih jelas dan tujuan pendidikan atau pembelajaran dapat tercapai dengan efektif dan efisien (Nurrita, 2018). Faktor lain yang harus dilakukan dalam mencapai profesionalisme guru adalah, perlunya perubahan paradigma dalam proses belajar mengajar (Shedriko et al., 2018).

Salah satu contoh media pembelajaran berbasis komputer yang paling sederhana dan mudah untuk dibuat guru adalah media pembelajaran berbasis Powerpoint (Ardiansah \& Miftakhi, 2019). Dalam penerapannya, PowerPoint dapat membantu pengajar dalam menyiapkan presentasi bahan ajar kepada siswa-siswi (Rusli et al., 2020). Dengan menggunakan PowerPoint, guru dapat membuat bahan ajar yang komunikatif dan interaktif. Namun dalam penggunaan PowerPoint harus diimbangi dengan pengembangan media belajar salah satunya dengan memanfaatkan tools yang ada di PowerPoint yang dapat membuat output video pembelajaran.

Pentingnya pengembangan media belajar dijelaskan peran pengembang teknologi pembelajaran (PTP) dalam mendukung pendidikan di Indonesia meliputi: 1. mengembangkan model teknologi pembelajaran; 2. mengembangkan media pembelajaran berbasis TIK; 3 . mengembangkan model aplikasi yang menunjang pembelajaran yang inovatif dan kreatif; dan 4. mengoptimalkan peran Rumah Belajar(Juanita et al., 2018).

Permasalahan para Guru dan tenaga pendidik MI Muhammadiyah Wangon sebagian besar menggunakan PowerPoint dalam menyajikan bahan ajar, dalam kondisi pandemi Covid-19. Dalam menyajikan materi masih berupa slide standar dan belum menginputkan animasi, suara, dan obyek yang menarik siswa didiknya. Para guru dituntut untuk dapat membuat bahan ajar salah satunya dalam bentuk video, dalam membuat video pembelajaran yang komunikatif dan menarik para guru masih merasa kesulitan karena kurang menguasai aplikasi-aplikasi editing video.

Dengan adanya pelatihan pembuatan video dengan menggunakan PowerPoint para guru dapat belajar membuat bahan ajar mulai dari mendesain dan mengatur letak tulisan, menginputkan animasi, suara/musik, obyek yang menarik dan menyusunnya dalam sebuah video pembelajaran yang komunikatif dan menarik.

\section{METODE}

Kegiatan PkM ini dilaksanakan di MI Muhammadiyah Wangon dengan peserta yang terdiri atas guru-guru di MI Muhammadiyah Wangon yang berjumlah 25 orang. Adapun metode pelaksanaan yang digunakan dalam kegiatan PkM ini yaitu berupa workshop.

Tahap persiapan dilakukan dengan mengurus ijin kepada pihak terkait, dan pertemuan dengan kepala sekolah beserta guru-guru di MI Muhammadiyah Wangon untuk menentukan waktu pelaksanaan PkM.

Tahap pelaksanaan dilakukan dengan memberikan materi pengenalan powerpoint diikuti dengan memberikan pelatihan pembuatan video pembelajaran menggunakan powerpoint.

Tahap evaluasi dilakukan untuk menilai tingkat pemahaman guru-guru peserta PkM terkait dengan materi pelatihan yang disampaikan oleh Tim.

\section{HASIL DAN PEMBAHASAN}

Pelatihan pembuatan video pembelajaran dengan menggunakan powerpoint di MI Muhammadiyah Wangon dibuka dengan sambutan bapak Samsuri, M.Pd. selaku Kepala MI Muhammadiyah Wangon. Harapan Kepala MI Muhammadiyah Wangon untuk kegiatan pelatihan ini dapat berjalan dengan lancar dan berkelanjutan di kemudian hari. Sambutan Kepala MI Muhammadiyah Wangon dapat dilihat pada Gambar 1.

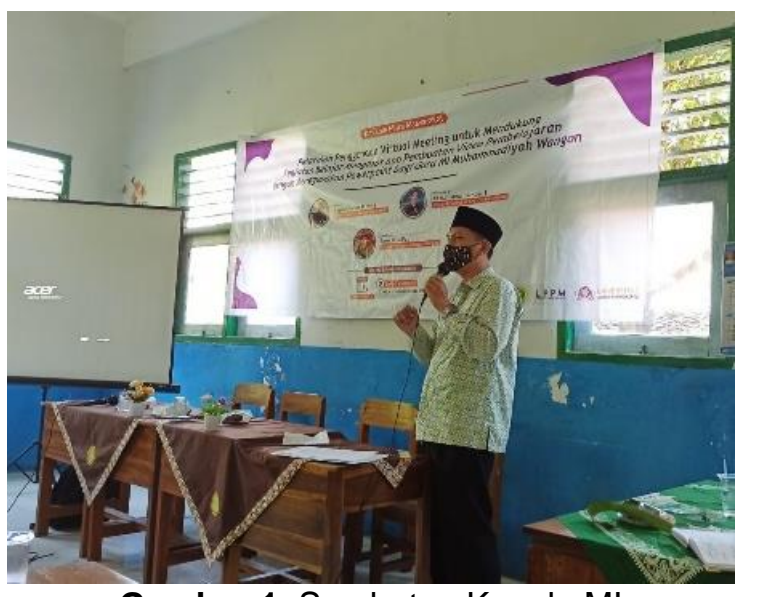

Gambar 1. Sambutan Kepala MI Muhammadiyah Wangon

Selanjutnya kegiatan pelatihan sepenuhnya diserahkan kepada tim PkM 
dengan melakukan pengenalan PowerPoint kepada peserta pelatihan dan menunjukkan contoh video pembelajaran dilanjutkan dengan acara inti yaitu pelatihan pembuatan video pembelajaran dengan menggunakan PowerPoint. Pelaksanaan pelatihan dilakukan dengan 1 pembicara sebagai pemandu para guru dalam menyusun slide PowerPoint yang dijadikan video pembelajaran dan 2 orang pendamping para guru yang membantu jika ada kesulitan dalam mengikuti pelatihan.

Kegiatan ini dilaksanakan dengan menyesuaikan kemampuan para peserta dalam mengikuti langkah-langkah dalam membuat video pembelajaran yang dapat dilihat pada Gambar 2.

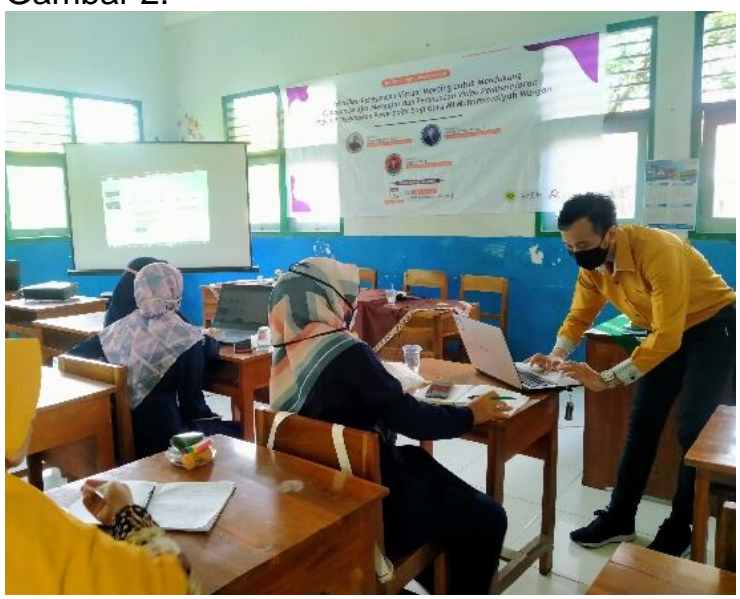

Gambar 2. Kegiatan pelatihan pembuatan video pembelajaran dengan menggunakan PowerPoint.

Para peserta mengikuti pelatihan dengan seksama dan langsung mempraktikan untuk keperluan bahan ajarnya seperti pada Gambar 3. Harapan dari peserta untuk kegiatan berupa pelatihan yang berkaitan dengan IT dapat diadakan secara rutin. Dengan adanya pelatihan mereka dapat menambah pengalaman dan pengetahuannya yang dapat digunakan untuk mendukung karirnya sebagai pendidik/guru.

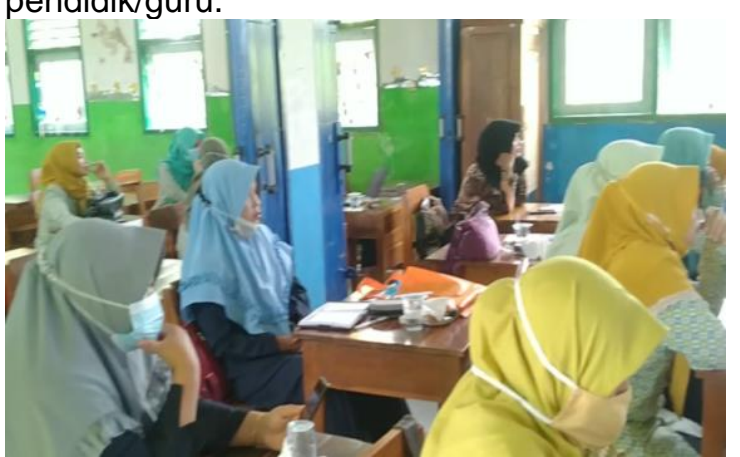

Gambar 3. Peserta mengikuti pelatihan dengan seksama

Kegiatan pelatihan pembuatan video pembelajaran dengan menggunakan
PowerPoint terlaksana dengan lancar dan sebagian besar peserta dapat mengikuti pelatihan dengan baik dan memahami cara membuat video pembelajaran dengan menggunakan PowerPoint. Acara pelatihan ditutup dengan foto bersama tim PkM dan para peserta seperti pada Gambar 4

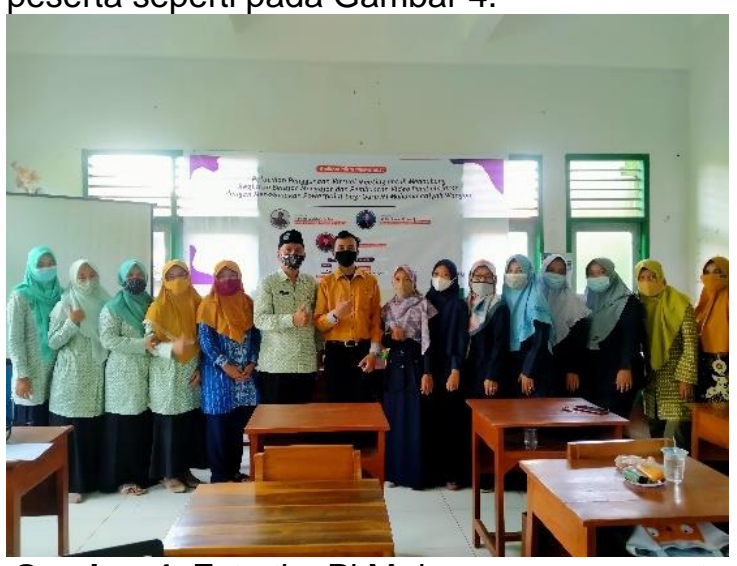

Gambar 4. Foto tim PkM dengan para peserta pelatihan pembuatan video pembelajaran dengan menggunakan PowerPoint

\section{SIMPULAN DAN SARAN}

Kegiatan pelatihan pembuatan video pembelajaran dengan menggunakan PowerPoint terlaksana dengan baik. Hal ini terbukti dengan antusias para peserta dalam mengikuti pelatihan dan langsung mempraktikan untuk membuat video pembelajaran sesuai dengan mata pelajaran yang diampu. Penggunaan PowerPoint ini sangat disarankan untuk para peserta didik dalam menyusun materi ajar baik berupa slide ataupun video agar dapat membuat bahan ajar yang komunikatif dan interaktif.

\section{UCAPAN TERIMAKASIH}

Penulis mengucapkan terima kasih kepada Universitas Amikom Purwokerto dan LPPM Universitas Amikom Purwokerto, yang menjadi sponsor sehingga kegiatan pengabdian kepada masyarakat ini dapat terealisasi.

\section{DAFTAR RUJUKAN}

Ardiansah, F., \& Miftakhi, D. R. (2019). Pelatihan Pembuatan Media Pembelajaran Interaktif Berbasis PowerPoint Bagi Tenaga Pendidik Paud Himpaudi Kecamatan Gabek Kota Pangkalpinang. Jurnal Pengabdian Pada Masyarakat Universitas Bangka Belitung, 6, 16-24.

EMIS. (2020). EMISPENDIS. http://emispendis.kemenag.go.id/dash board/index. php?content=madrasah\&a ction=lbg\&nss=111233020003.

Juanita, S., Hayati, P., \& Sakti, D. V. S. Y. 
(2018).

KETERAMPILAN MENYAJIKAN

PRESENTASI MENARIK DAN

INTERAKTIF BAGI GURU

PKBMNEGERI 27 PETUKANGAN

DENGAN PELATIHAN MICROSOFT POWERPOINT. SEBATIK, 528-533.

Nurrita, T. (2018). Development of circle learning media to improve student learning outcomes. Journal of Physics: Conference Series, 03(01), 171-187. https://doi.org/10.1088/1742-

6596/1321/2/022099

Rusli, M., Winarso, E., \& Putri, D. (2020). Pelatihan Microsoft Powerpoint Dasar Bagi Guru Guru Paud Kabupaten Bekasi. Jurnal Pengabdian Kepada Masyarakat, 1(1), 12-15. http://112.78.142.42/index.php/kalbisa bdimas/article/view/22

Shedriko, Setiawan, H. S., \& Kusmayadi. (2018). Pelatihan Perangkat Lunak Powerpoint untuk Meningkatkan Kinerja Guru di SD dan SMP 19 Muhammadiyah Sawangan Depok. Jurnal PKM: Pengabdian Kepada Masyarakat, 151158. 